\title{
MUNICIPALITIES OF HIGHER VULNERABILITY TO SYLVATIC YELLOW FEVER OCCURRENCE IN THE SÃO PAULO STATE, BRAZIL
}

Eduardo Stramandinoli MORENO \& Rita de Cássia Barradas BARATA

\begin{abstract}
SUMMARY
Until 1999 the endemic cases of Sylvatic Yellow Fever were located in the states of northern, midwestern and pre-Amazon regions. Since then, the disease progressively expanded its territory of occurrence, cases being registered beyond the traditional boundaries of endemism. The São Paulo State is considered to be part of this context, since after decades without registration of autochthonous cases of the disease, it reported, in 2000 and 2008-2009, epizootic occurrence in non-human primates and 30 cases in humans. Facts like these, added to the increase in incidences of serious adverse effects resulting from the Yellow Fever vaccination, have highlighted the importance of defining priority municipalities for vaccination against the disease in the state. Two groups of municipalities, some affected and some non-affected by YF, were compared for environmental variables related to the eco-epidemiology of the disease according to literature. The Multiple Correspondence Analysis (MCA) was used to pinpoint the factor able to differentiate the two groups of municipalities and define the levels of risk. The southeast region of the São Paulo State was considered to be the area with a higher number of municipalities classified as high risk and should be considered a priority for the application of prevention measures against Yellow Fever.
\end{abstract}

KEYWORDS: Yellow Fever; Risk assessment; Environment; Vaccination.

\section{INTRODUCTION}

Yellow Fever (YF) shows two distinct epidemiological cycles, Sylvatic and Urban, which are distinguished fundamentally by the vector involved with the transmission and by the sources of infection ${ }^{8,11}$. The Sylvatic Yellow Fever (SYF) is endemic in tropical regions of Africa and the Americas. Cases of the disease have been reported between the parallels $12^{\circ} \mathrm{N}$ and $12^{\circ} \mathrm{S}^{25}$. In Brazil, the major period of occurrence of the disease is during the months from January to April, when increases are observed in both the rainfall patterns and the density of the vectors of the disease, coinciding with the period of major activity for agriculture and animal husbandry ${ }^{19,20,23}$.

Until 1999 the endemic cases were located in the states of northern, midwestern and pre-Amazon regions, as well as some sporadic cases in the western part of the Minas Gerais State ${ }^{2}$. Since then, Sylvatic Yellow Fever progressively expanded its territory of occurrence, a gradual increase in cases of the disease being observed near to the traditional boundaries of the endemic zone.

In the outbreaks that occurred in the period of 2000/2003, it was possible to observe an expansion of the viral circulation in the southeastern part of the country, its presence being detected in silent areas for decades, which imposed a need for a redefinition of risk areas ${ }^{3}$.
In 2000, two autochthonous human cases of Sylvatic Yellow Fever were reported in the northwestern region of the São Paulo State ${ }^{22}$. In 2008, more cases were reported in the same region, namely two autochthonous human cases confirmed in the region of Ribeirao Preto and epizootic occurrences in non-human primates confirmed in the region of São Jose do Rio Preto ${ }^{21}$. In 2009 cases emerged in the mid-southern region of the state, 30 human cases and epizootic occurrences in non-human primates being confirmed as $\mathrm{YF}^{2,10}$. The outbreaks occurred in five different municipalities, and led the Public Health authorities of the state to expand the area to be indicated for vaccination against Yellow Fever ${ }^{4,10}$.

In Brazil, up to 2008, four epidemiologically distinct zones were defined for Sylvatic Yellow Fever: the endemic zone (indicated for vaccination against YF), the transition zone (also known as the epizootic or emergency area), the potential risk zone (not indicated for vaccination against YF) and the indene zone (not indicated for vaccination against YF) $)^{3,5,12}$. The "transition" and "potential risk" zones did not have any registered human cases and so did not require any indication for vaccination against the disease. However, the fact that these areas share some boundaries with areas confirmed for circulation of Yellow Fever Virus (YFV) and present some favorable environmental conditions for the establishment and maintenance of YF generated the need for special attention, and resulted in them being monitored more closely. However, the criteria for the delimitation of these areas were largely subjective, and 


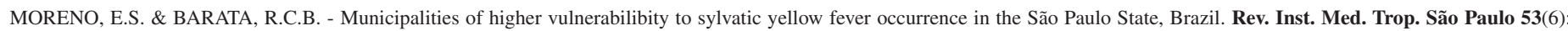
$335-9,2011$

the lack of vaccinations for populations considered to be at risk created some ethical problems for the public-health authorities of Brazil, who decided, from 2008, to eliminate the zones of "transition" and "potential risk". So, the areas currently recognized are only the endemic (indicated for vaccination against YF) and indene (not indicated for vaccination against YF) areas.

The municipalities indicated for vaccination against YF, in emergency situations, like in an outbreak period, are considered to be "affected" or "vaccination-expanded" areas. Thus, municipalities which showed evidence of viral circulation, such as: epizootic occurrence in non-human primates confirmed for YF, as well as confirmed human cases or isolation of the virus in mosquito vectors, are considered to be "affected". Municipalities which are located up to $30 \mathrm{~km}$ from an affected municipality are considered to be "vaccination-expanded" areas.

The Yellow Fever vaccine used in Brazil is produced by the Oswaldo Cruz Foundation/Biomanguinhos, by the replication of the YFV strain 17D (sub-strain 17DD) in Specific-Pathogen-Free chicken embryos. The vaccine was considered to be totally safe until 2001, up to which point there had been no reports of serious adverse effects related to its administration.

In 2001, however, 12 cases were described ${ }^{6,9,24}$, and an additional 39 cases were reported worldwide up to $2009^{1}$, totaling more than 50 cases until this moment ${ }^{1,15,16}$. Two types of serious adverse effects are commonly reported: neurotropic disease caused by the invasion of the vaccine strain into the central nervous system; and viscerotropic disease, a pansystemic infection that is frequently accompanied by hepatic failure, a condition closely related to the infection by the wild virus ${ }^{1,18}$.

The risk factors for the development of these two post-vaccination syndromes have not yet been adequately described. Some descriptive studies defined three main potential risk factors: 60 years of age or more $^{7,17}$, male gender and a history of immunosuppression ${ }^{14}$.

These facts have generated a dilemma for the public-health authorities: what proportion of the at-risk population should be vaccinated to minimize the total number of cases due to both the natural infection by YFV as well as the 17DD vaccine strain?

The public-health authorities of the São Paulo State are currently under pressure to define vaccination strategies for the containment of the geographic expansion of the disease. So, this study has as goals identifying risk areas for SYF in municipalities currently located outside of the area indicated for vaccination against YF in the São Paulo State, in order to identify those with higher vulnerability to the disease's occurrence.

\section{METHODS}

Study Area: The São Paulo State is composed of 645 municipalities, of which 216 are currently located outside of the area indicated for vaccination against YF. The state operates a surveillance system divided into 33 Regional Groups (RG), in such a way that 13 of these are located in areas not indicated for vaccination against YF.

These municipalities represent the area with the highest population density in the state and one of the highest in the country.
Figure 1 shows the expansion over time of the areas indicated for vaccination against YF in the São Paulo State between 2000 and 2009, in accordance with the criteria of the Brazilian Ministry of Health.

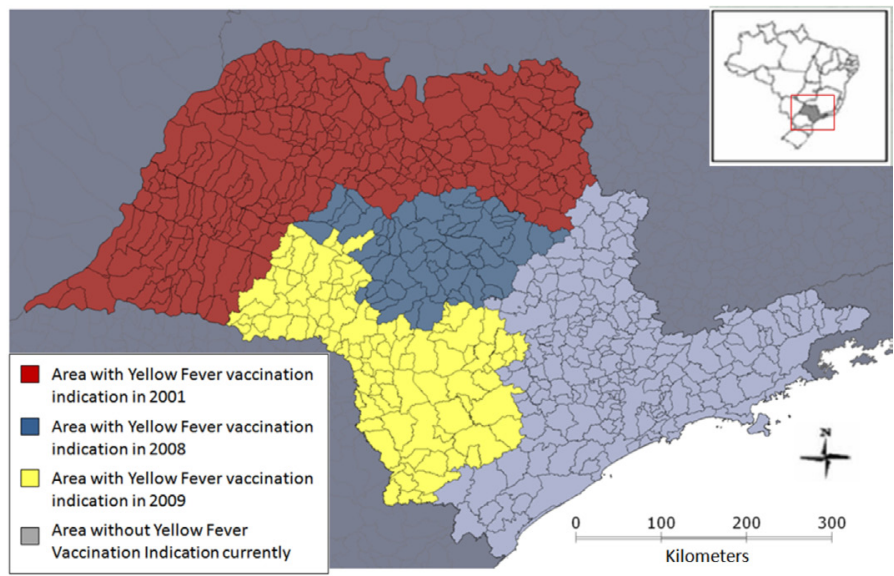

Fig. 1 - Expansion over time of areas indicated for vaccination against Yellow Fever, São Paulo State, Brazil. 2000-2009.

Methodology for risk assessment: For the selection of variables related to exposition, vulnerability and resilience to Yellow Fever a casecontrol design with an ecological approach was developed ${ }^{13,14}$.

To this end, cases were considered in municipalities with confirmed viral circulation (either epizootic occurrence in non-human primates or human cases confirmed by epidemiological or laboratorial criteria, or isolation of YFV in mosquito vectors); or municipalities with adjacent boundaries up to $30 \mathrm{~km}$ from an affected municipality.

The other municipalities of the state were considered as controls, since they were located at least $100 \mathrm{~km}$ from any affected municipality. For each group (both affected and non-affected), 30 municipalities were randomly selected and compared using the Qui-square test (5\% significance) for variables potentially related to the eco-epidemiology of Yellow Fever. The variables shown to be associated with the viral circulation $(p$ value $<0.05$ ) were selected for the Multiple Correspondences Analysis (MCA).

Table 1 shows this group of variables and its respective weights (indicated by the MCA) to explain the total variability between the two groups of municipalities studied.

The MCA generated a factor, designated "F-factor", which represents the level of vulnerability of each municipality to the occurrence of Yellow Fever in its territory, and is calculated by the sum of the weights attributed to each variable.

The factor has an amplitude which varies from -5.5 to 5.5 , such that values below 0 represent low risk, values from 0 to 2.0 represent medium risk and values above 2.0 represent high risk of the disease's occurrence. Thus, the F-factor was calculated for the 216 municipalities in the area currently not indicated for vaccination against YF in the State of São Paulo. 
Table 1

Weights for each variable used for the calculation of the F-factor, obtained by the MCA

\begin{tabular}{lr}
\hline Variables & Weight \\
\hline Distance for YF vaccination indicated area - till 30 km & 0.306264 \\
Distance for YF vaccination indicated area - 31 to $100 \mathrm{~km}$ & 0.244947 \\
Distance for YF vaccination indicated area - higher than $100 \mathrm{~km}$ & -0.78091 \\
Distance for Biodiversity conservation unite - till $30 \mathrm{~km}$ & 0.648733 \\
Distance for Biodiversity conservation unite - 31 to $100 \mathrm{~km}$ & 0.013377 \\
Distance for Biodiversity conservation unite - higher than $100 \mathrm{~km}$ & -1.06924 \\
Riparian forest proportion - till 30\% & -0.71405 \\
Riparian forest proportion - 31 to 60\% & -0.24182 \\
Riparian forest proportion - 61 to 100\% & 0.932843 \\
Number of main routes of illegal wildlife traffic - Low & -0.85655 \\
Number of main routes of illegal wildlife traffic - Medium & -0.65112 \\
Number of main routes of illegal wildlife traffic - High & 1.087954 \\
Dominant Wind Route direction influence - Low & -0.63524 \\
Dominant Wind Route direction influence - Medium & 0.073681 \\
Dominant Wind Route direction influence - High & 1.123113 \\
Humidity - (Pluviosity/RET) - less than 1,5 & -0.93357 \\
Humidity (Pluviosity/RET) - higher than 1,5 & 0.400103 \\
Surveillance for SFHS - Yes & -0.64806 \\
Surveillance for SFHS - No & 0.847463 \\
\hline
\end{tabular}

\section{RESULTS}

According to the model, among the 216 municipalities located in areas currently not indicated for vaccination against Yellow Fever, 137 $(63.5 \%)$ showed low risk, 53 (24.5\%) showed risk and $25(12 \%)$ showed high risk.

Figure 2 shows the distribution of the 216 municipalities located in areas not indicated for vaccination against Yellow Fever, according to the F-factor:
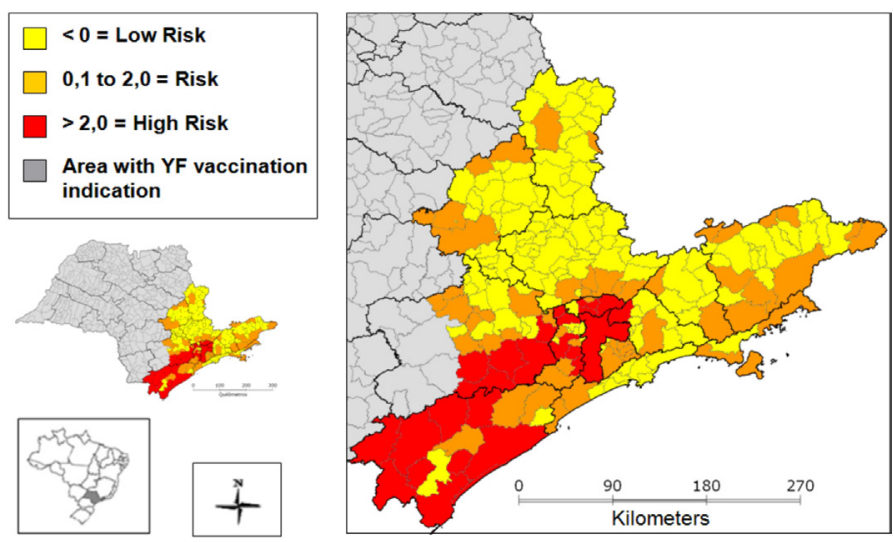

Fig. 2 - Distribution of municipalities located in areas not indicated for vaccination against $\mathrm{YF}$, in accordance with F-factor.

\section{DISCUSSION}

The YF surveillance system in Brazil functions based on confirmed cases, not including in its objectives prediction of the disease's occurrence in places with potential risk. The main goals of this system are principally focused on fast detection of cases of the disease for the rapid implementation of emergency measures, in order to prevent an epidemic outbreak ${ }^{3}$. The old approach to risk classification of YF in Brazil, which used areas of "transition" and "potential risk" to guide the control measures, allowed for the intensification of surveillance in those areas with known environmental potential for the establishment of the disease ${ }^{5,12}$. This approach, however, was highly subjective, since the criteria for area designation were not described in a systematic way. This generated difficulties in the implementation of action measures, and so it was simplified to the current method.

However, it is of extreme importance that a surveillance system like that for Yellow Fever - a fatal disease with a big epidemic potential - works with predictive models, so as to coordinate action measures in outbreak situations, as well as, in the long term, aiming to break the disease's expansion into big populated areas or known vulnerable populations.

The application of this standardized methodology to the municipalities not indicated for vaccination against YF pointed towards the south-east region of the São Paulo State as the most vulnerable to the disease's occurrence. In this region there is located a large Biodiversity Conservation Unit: The State Touristic Park of "Alto do Ribeira" (PETAR), and thus several attributes considered for the F-factor calculation are concentrated there. The region has more than 120 thousand hectares, constituting an ecologic continuum connecting affected areas with the most populated region in the state.

Another group classified "at risk" for SYF occurrence is located in the metropolitan region of the city of São Paulo, which has more than 20 million inhabitants. Despite its extensive urban development, this region has patches of natural forest and environments potentially able to maintain the YFV. So, these municipalities could function as 'stepping stones' for the expansion of the virus in the direction of the most populated region of Brazil, potentially increasing the urban risk of YFV.

In this sense, it is recommended that RGs that are subject to epidemiologic surveillance, which have municipalities classified as "at risk" in its coverage area, pass through an analysis of its structural capacity for the confrontation of a Yellow Fever outbreak. This analysis should consider the following: the number of technicians trained and sensitized for the detection of YF suspected cases, its treatment and laboratorial diagnosis resources; viability for the detection of epizootic occurrence in non-human primates; capacity for the conduction of entomological studies; and viability for the timely implementation of vaccination campaigns for target populations when required.

In the case of RGs that have municipalities classified as "high risk", it is recommended that, in addition to the measures cited above, in the short term, the following be carried out: the organization of a surveillance system for Icterohemorrhagic Fever Syndrome (SIHFS), once this system increased the sensibility of the Yellow Fever Surveillance System, in other regions of the state affected by the disease. 


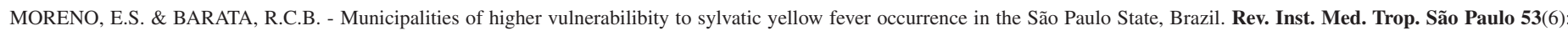
$335-9,2011$.

In the case that some of the high-risk regions are highly populated, it is recommended that RGs with higher populations be given priority. Currently, the region which greatest concentration of high-risk municipalities is the RG coverage area "Registro", located in Vale do Ribeira, in the southeastern region of the state.

\section{CONCLUSIONS}

The southeastern region of the State of São Paulo (RG Registro) is the region with the highest vulnerability to the occurrence of Sylvatic Yellow Fever in its territory. These municipalities have priority for vaccination against the disease in the state. The methodology used in this study had as its objective municipalities differentiated according to its vulnerability to YF occurrence, identified by a systematic design. The utilization of predictive methodologies can help the health professionals involved to make decisions during vaccination campaigns. Whether re-incorporated into the Yellow Fever Surveillance System as a complementary tool or not, predictive methodologies like this must be standardized and contextualized for each state or region, in order to avoid the subjectivity and difficulty of implementation of methods used in the past.

\section{RESUMO}

\section{Municípios de alta vulnerabilidade à ocorrência da febre amarela silvestre no Estado de São Paulo, Brasil}

Até o ano de 1999, no Brasil, casos endêmicos de Febre Amarela Silvestre estavam localizados nos estados das regiões Norte, CentroOeste e pré-amazônica. Desde então, a doença vem progressivamente expandindo seu território de ocorrência, sendo registrados casos além das fronteiras tradicionais de endemismo. Neste contexto se insere o estado de São Paulo que, após décadas sem registro de casos autóctones da doença, reportou em 2000 e 2008-2009 epizootias em primatas não humanos e 30 casos humanos. Fatos como este, somados a crescente incidência de eventos adversos graves relacionados à vacinação contra Febre Amarela, demonstram a importância de serem definidos municípios prioritários para a vacinação contra a doença no estado. Assim, dois grupos de municípios, afetados e não-afetados pela Febre Amarela, foram comparados para variáveis ambientais relacionadas com a eco-epidemiologia da doença segundo a literatura. A Análise por Correspondência Múltipla foi utilizada para gerar um fator capaz de diferenciar os dois grupos de municípios e definir os níveis de risco. Após aplicação da metodologia para os municípios atualmente localizados fora da área de recomendação de vacinação contra Febre Amarela, a região sudeste do estado foi considerada prioritária para aplicação de medidas preventivas contra a doença.

\section{REFERENCES}

1. Barrett ADT, Teuwen DE. Yellow fever vaccine - how does it work and why do rare cases of serious adverse events take place? Curr Opin Immunol. 2009;21:308-13.

2. Brasil, Ministério da Saúde, Secretaria de Vigilância em Saúde. Boletim Eletrônico Epidemiológico, Situação Epidemiológica das Zoonoses de Interesse à Saúde Pública. 2009. Available from: http://portal.saude.gov.br/portal/arquivos/pdf/ boletim_epidemiologico_zoonoses_0 62009.pdf.

3. Brasil, Ministério da Saúde, Secretaria de Vigilância em Saúde. Guia de vigilância epidemiológica - Febre Amarela. $7^{a}$ ed. Brasília: Ministério da Saúde; 2010. p. 23-37. (Série A. Normas e Manuais Técnicos). Available from: http://bvsms.saude.gov.br/ bvs/publicacoes/Guia_Vig_Epid_novo2.pdf
4. Brasil, Ministério da Saúde, Secretaria de Vigilância em Saúde. Emergências em saúde pública de importância nacional (ESPIN) de febre amarela silvestre em São Paulo e no Rio Grande do Sul e a situação epidemiológica atual no Brasil (2008/2009). 2009. Available from: http://portal.saude.gov.br/portal/arquivos/pdf/ boletim_febre_amarela_09_12_09.pdf

5. Brasil, Ministério da Saúde, Secretaria de Vigilância em Saúde. Guia de vigilância epidemiológica - Febre amarela. $6^{\text {a }}$ ed. Brasília: Ministério da Saude; 2005. p. $307-$ 24. (Série A. Normas e Manuais Técnicos). Available from: http://bvsms.saude.gov. br/bvs/publicacoes/Guia_Vig_Epid_novo2.pdf

6. Camacho LAB, de Aguiar SG, Freire M da S, Leal M da L, do Nascimento JP, Iguchi $\mathrm{T}$, et al. Reactogenicity of yellow fever vaccines in a randomized, placebo-controlled trial. Rev Saúde Pública. 2005;39:413-20.

7. Centers for Disease Control and Prevention (CDC). Adverse events associated with 17D-derived vaccination: United States, 2001-2002. MMWR Morb Mortal Wkly Rep. 2002;51:989-93.

8. Chadee DD, Tikasingh ES, Ganesh R. Seasonality, biting cycle and parity of the yellow fever vector mosquito Haemagogus janthinomys in Trinidad. Med Vet Entomol. 1992;6:143-8.

9. Chan RC, Penney DJ, Little D, Carter IW, Roberts JA, Rawlinson WD. Hepatitis and death following vaccination with 17D-204 yellow fever vaccine. Lancet. 2001;358:121-2.

10. CVE - Informe Técnico. Centro de Vigilância Epidemiológica de São Paulo (CVE). Febre amarela silvestre no Estado de São Paulo, 2009. 2009. Available from: ftp:// ftp.cve.saude.sp.gov.br/doc_tec/ZOO/Boletim_FASP171209.pdf

11. Dégallier N, Rosa APAT, Vasconcelos PFC, Rosa EST, Rodrigues SG, Sá Filho GC, et al. New entomological and virological data on the vectors of sylvatic yellow fever in Brazil. Cienc Cult.1992;44:136-42.

12. FUNASA. Fundação Nacional de Saúde. Manual de vigilância epidemiológica de febre amarela. Brasília: FNS; 1999. Available from: http://portal.saude.gov.br/portal/ arquivos/pdf/manu_feam.pdf

13. Haneuse S, Wakefield J. The combination of ecological and case-control data. University of Washington; 2006. (UW Biostatistics Working Paper Series, Paper 332). Available from: http://www.bepress.com/uwbiostat/paper332.

14. Haneuse S, Wakefield J. Hierarchical models for combining ecological and casecontrol data. University of Washington; 2006. (UW Biostatistics Working Paper Series, Paper 287). Available from: http://www.bepress.com/uwbiostat/paper287.

15. Hayes EB. Acute viscerotropic disease following vaccination against yellow fever. Trans R Soc Trop Med Hyg. 2007;101:967-71.

16. Lindsey NP, Schroeder BA, Miller ER, Braun MM, Hinckley AF, Marano N, et al. Adverse event reports following yellow fever vaccination. Vaccine. 2008;26:6077-82.

17. Martin M, Weld LH, Tsai TF, Mootrey GT, Chen RT, Niu M, et al. Advanced age a risk factor for illness temporally associated with yellow fever vaccination. Emerg Infect Dis. 2001;7:945-51.

18. McMahon AW, Eidex RB, Marfin AA, Russell M, Sejvar JJ, Markoff L, et al. Neurologic disease associated with 17D-204 yellow fever vaccination: a report of 15 cases. Vaccine. 2007;25:1727-34.

19. Monath TP. Epidemiology of yellow fever: current status and speculations on future trends. In: Saluzzo JF, Dodet B, editors. Factors in the emergence of arbovirus diseases. Paris: Elsevier; 1997. p. 143-56.

20. Monath TP. Yellow fever: an update. Lancet Infect Dis. 2001;1:11-20.

21. Moreno ES, Rocco IM, Bergo ES, Brasil RS, Siciliano MM, Suzuki A, et al. Reemergence of yellow fever: detection of transmission in the State of São Paulo, Brazil, 2008. Rev Soc Bras Med Trop. 2011;44:290-6. 


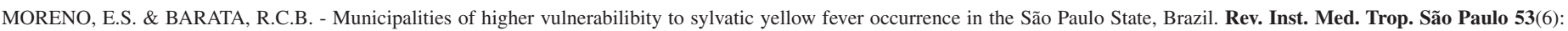
$335-9,2011$.

22. Rocco I, Katz G; Tubaki RM. Febre amarela silvestre no Estado de São Paulo, Brasil: casos humanos autóctones. Rev Inst Adolfo Lutz. 2003;62:201-6.

23. Tomori O. Yellow fever: the recurring plague. Crit Rev Clin Lab Sci. 2004;14:391427.
24. Vasconcelos PFC, Luna EJ, Galler R, Silva LJ, Coimbra TL, Barros VL, et al. Serious adverse events associated with yellow fever 17DD vaccine in Brazil: a report of two cases. Lancet. 2001;358:91-7.

25. Vasconcelos PFC. Febre amarela. Rev Soc Bras Med Trop. 2003;36:275-93.

Received: 31 August 2011

Accepted: 21 October 2011 